\title{
OPTIMALISASI PEMBANGUNAN PERUMAHAN DENGAN MENGGUNAKAN METODE SIMPLEKS (STUDI KASUS: UD. PERUMAHAN GRIYA CEMPAKA ALAM)
}

\author{
H. Natalia ${ }^{1}$, A. Sahari², A. I. Jaya ${ }^{3}$ \\ 1,2,3 Program Studi Matematika Jurusan Matematika FMIPA Universitas Tadulako \\ Jalan Soekarno-Hatta Km. 09 Tondo, Palu 94118, Indonesia. \\ 1heinny_Bati@yahoo.com, 2agus_sh@yahoo.com, 3jayaindraagus@gmail.com
}

\begin{abstract}
Housing is one of the basic human needs. As the increasing of the human population, the need for homes is also increasing. Seeing this opportunity many developers offer a recidential house. One of the developers in the city of Palu is UD. Griya Cempaka Alam which offers four different types of houses, namely the type 80, type 57, type 50 and type 42. To obtain the optimum amount of each type of house that will be built as well as benefits in accordance with the limits available, then set up a model the optimization calculate is using the simplex method. The analysis showed that the optimum number of houses to be built on any type that are homes of 80 types are 4 units, homes as many as 24 units of type 57, type 50 homes 3 units and 42 types of homes 14 units and the maximum benefit is obtained UD. Griya Cempaka Alam which amounted to Rp 2.484.000.000.-.
\end{abstract}

\section{Keywords : Home Type, Housing, Optimum, Simplex Method}

\section{ABSTRAK}

Perumahan merupakan salah satu kebutuhan dasar manusia. Seiring peningkatan jumlah populasi manusia, maka kebutuhan akan rumah juga meningkat. Melihat keadaan ini banyak pengembang menawarkan jasa penyedia rumah tempat tinggal. Salah satu pengembang perumahan di Kota Palu adalah UD. Perumahan Griya Cempaka Alam yang menawarkan empat macam tipe rumah, yaitu tipe 80, tipe 57, tipe 50 dan tipe 42 . Untuk mendapatkan jumlah optimal setiap tipe rumah yang akan dibangun serta keuntungan yang sesuai dengan batasan-batasan yang tersedia, maka dibentuk model optimalisasi untuk menghitung berapa jumlah masingmasing tipe rumah yang akan dibangun dengan menggunakan metode simpleks. Hasil analisis menunjukkan optimum jumlah rumah yang akan dibangun pada setiap tipe yaitu rumah tipe 80 sebanyak 4 unit, rumah tipe 57 sebanyak 24 unit, rumah tipe 50 sebanyak 3 unit dan rumah tipe 42 sebanyak 14 unit dan keuntungan maksimal yang diperoleh UD. Perumahan Griya Cempaka Alam yaitu sebesar Rp 2.484.000.000.-.

Kata Kunci $\quad$ : Metode Simpleks, Optimal, Perumahan, Tipe Rumah 


\section{PENDAHULUAN}

\subsection{Latar Belakang}

Perumahan merupakan salah satu kebutuhan dasar manusia. Seiring dengan perkembangan zaman, berkembang pula jumlah manusia yang berakibat pada semakin berkembangannya kebutuhan akan rumah. Melihat keadaan ini banyak pengembang yang bermunculan untuk menyediakan rumah tempat tinggal. Rumah yang dikembangkan mulai dari rumah tipe sangat sederhana sampai tipe rumah mewah. Pengembang biasanya lebih tertarik mengembangkan tipe rumah mewah karena lebih menguntungkan dibandingkan jika mengembangkan tipe rumah sederhana. Namun di sisi lain masyarakat lebih banyak membutuhkan tipe rumah sederhana sesuai kemampuan mereka. Kebutuhan masyarakat yang tinggi terhadap tipe rumah sederhana merupakan permasalahan bagi pemerintah dalam rangka meningkatkan kualitas kehidupan masyarakat.

Menyadari akan pentingnya kebutuhan rumah tersebut, pemerintah telah berusaha untuk mencari jalan agar pemerataan pemilikan rumah dapat dinikmati oleh masyarakat. Di dalam upaya pemerintah untuk mewujudkan cita-citanya maka peranan swasta sangat diharapkan dapat membantu pemerintah untuk menyiapkan lokasi-lokasi perumahan yang ideal serta membangun kompleks-kompleks Perumahan dan Rumah Susun. Kesempatan dan peluang yang diberikan kepada swasta tersebut diharapkan hasilnya dapat betul-betul terwujud (Heinz Frick, 1999).

Salah satu pengembang perumahan di Kota Palu adalah UD. Perumahan Griya Cempaka Alam yang menawarkan empat macam tipe rumah, yaitu tipe 42 , tipe 50 , tipe 57 , dan tipe 80. Perumahan Griya Cempaka Alam merupakan hunian yang nyaman dan strategis, karena berada diperbatasan Kota Palu dan Kabupaten Sigi. Perumahan ini masih dalam tahap pengembangan dengan luas lahan yang tersedia 1,5 hektar.

Program linier sebagai suatu teknik analisis kuantitatif merupakan model matematika yang dapat diterapkan dalam pengambilan keputusan yang berhubungan dengan keterbatasan sumber daya demi mencapai tujuan yang optimal. Dari problem pembangunan perumahan, program linier dengan metode simpleks juga dapat digunakan untuk mendapatkan keuntungan maksimal. Dimana metode simpleks merupakan suatu metode yang secara sistematis dimulai dari suatu penyelesaian dasar yang fisibel ke pemecahan dasar fisibel lainnya, yang dilakukan berulang-ulang (iteratif) sehingga tercapai suatu penyelesaian optimum (Siringoringo, 2008). Penyelesaian dari masalah ini dikerjakan dengan software $Q M$ for windows. 


\subsection{Rumusan Masalah}

Berdasarkan latar belakang di atas maka rumusan masalah yang diambil adalah :

1. Berapa jumlah optimum setiap tipe rumah yang akan dibangun sesuai dengan batasan-batasan yang tersedia?

2. Berapa keuntungan maksimum pada pembangunan perumahan yang dilakukan oleh UD. Perumahan Griya Cempaka Alam?

\subsection{Tujuan}

Berdasarkan rumusan masalah di atas maka tujuan dari penelitian ini adalah :

1. Memperoleh jumlah optimal setiap tipe rumah yang akan dibangun sesuai dengan batasan-batasan yang tersedia.

2. Mendapatkan keuntungan maksimal dari pembangunan perumahan yang dilakukan oleh UD. Perumahan Griya Cempaka Alam.

\subsection{Batasan Penelitian}

Penelitian ini dibatasi menjadi lima variabel yaitu tipe rumah, luas lahan, biaya produksi, waktu pelaksanaan pembangunan dan permintaan pasar. Selain itu bentuk geometri dari lahan yang akan dibangun tidak diperhitungkan.

\section{METODE PENELITIAN}

Prosedur penelitian ini adalah sebagai berikut:

1. Menganalisa masalah

2. Melakukan studi literatur dengan mengumpulkan materi dari buku-buku, artikel dan jurnal yang di dapat dari perpustakaan dan perpustakaan online, kemudian membuat model optimalisasi dari data yang diperoleh

3. Menerapkan Metode Simpleks dalam optimalisasi jumlah tipe rumah yang akan dibangun

4. Mendapatkan hasil dari Metode Simpleks dengan menggunakan QM for Windows kemudian disimpulkan.

\section{HASIL DAN PEMBAHASAN}

\subsection{Pengumpulan data}

Tabel 1 : Data Perumahan UD. Griya Cempaka Alam

\begin{tabular}{|c|c|c|c|c|c|c|}
\hline No. & Uraian & Tipe 80 & Tipe 57 & Tipe 50 & Tipe 42 & Batasan \\
\hline 1 & $\begin{array}{c}\text { Harga } \\
\text { produksi }\end{array}$ & Rp 320.000.000 & Rp 248.000.000 & Rp 192.000.000 & Rp 152.000.000 & 10 Milyar \\
\hline
\end{tabular}




\begin{tabular}{|c|c|c|c|c|c|c|}
\hline 2 & Luas Tanah & $108 \mathrm{~m}^{2}$ & $108 \mathrm{~m}^{2}$ & $98 \mathrm{~m}^{2}$ & $98 \mathrm{~m}^{2}$ & $15000 \mathrm{~m}^{2}$ \\
\hline 3 & Harga Jual & $\operatorname{Rp~400.000.000}$ & $\operatorname{Rp~310.000.000}$ & $\operatorname{Rp~240.000.000}$ & $\operatorname{Rp~190.000.000}$ & - \\
\hline 4 & $\begin{array}{c}\text { Selisi harga } \\
\text { jual - harga } \\
\text { produksi }\end{array}$ & $\operatorname{Rp~80.000.000}$ & $\operatorname{Rp~62.000.000}$ & $\operatorname{Rp~48.000.000}$ & $\operatorname{Rp~38.000.000}$ & - \\
\hline
\end{tabular}

Sumber : UD. Perumahan Griya Cempaka Alam

\subsection{Formulasi Fungsi Kendala dan Fungsi Tujuan dengan Metode Simpleks}

Metode simpleks ialah suatu metode yang secara sistematis dimulai dari suatu pemecahan dasar yang fisibel ke pemecahan dasar yang fisibel lainnya dan ini dilakukan berulang-ulang sehingga tercapai suatu pemecahan yang optimum. Penentuan solusi optimal menggunakan metode simpleks didasarkan pada teknik eliminasi Gauss Jordan. Penentuan solusi optimal dilakukan dengan memeriksa titik ekstrim satu per satu dengan cara perhitungan iteratif yang disebut dengan iterasi (dengan jumlah iterasi yang terbatas) sehingga pada akhirnya akan tercapai sesuatu pemecahan dasar yang optimum dan setiap langkah menghasilkan suatu nilai dari fungsi tujuan yang selalu lebih optimal atau sama dari langkah-langkah sebelumnya (Siringoringo, 2008).

Metode Simpleks merupakan suatu proses dimana suatu prosedur sistematis diulangulang (iterasi) sampai hasil yang diinginkan tercapai. Oleh karena itu metode ini mengganti satu masalah yang sulit dengan serangkaian masalah yang mudah.

Dalam linear programming dikenal dua macam fungsi yaitu :

1. Fungsi tujuan : mengarahkan analisa untuk mendeteksi tujuan perumusan masalah

2. Fungsi kendala : untuk mengetahui sumber daya yang tersedia dan permintaan atas sumber daya tersebut.

Masalah diatas dapat diformulasikan sebagai fungsi kendala, yaitu dengan cara berikut :

a. Batasan Biaya Produksi

Dana yang tersedia untuk pembuatan rumah dengan 4 macam tipe maksimum 10 milyar rupiah. Formulasi fungsi batasan biaya produksi yaitu :

$320 x_{1}+248 x_{2}+192 x_{3}+152 x_{4} \leq 10000$,diubah menjadi

$320 x_{1}+248 x_{2}+192 x_{3}+152 x_{4}+S_{1}=1000$

\section{b. Batasan Luas Lahan}

Luas lahan yang dikembangkan adalah $15000 \mathrm{~m}^{2}$. Sedangkan luas infrastuktur adalah $2500 \mathrm{~m}^{2}$. Jadi luas lahan yang tersedia untuk mendirikan bangunan rumah yang terdiri dari empat 
tipe adalah maksimum seluas $12500 \mathrm{~m}^{2}$. Formulasi fungsi kendala dengan batasan luas lahan yaitu : $108 x_{1}+108 x_{2}+98 x_{3}+98 x_{4} \leq 12500$, diubah menjadi $108 x_{1}+108 x_{2}+98 x_{3}+98 x_{4}+S_{2}=12500$

\section{c. Batasan waktu pembangunan}

Untuk membangun semua tipe rumah direncanakan selesai dalam waktu 52 minggu (1 Tahun). Formulasi kendala dengan batasan waktu pembangunan yaitu :

$x_{1}+x_{2}+x_{3}+x_{4} \leq 52$, diubah menjadi

$x_{1}+x_{2}+x_{3}+x_{4}+S_{3}=52$

\section{d. Batasan permintaan pasar}

Berdasarkan proporsi tipe penjualan (aspek pasar) proporsi tipe rumah diminati yaitu tipe rumah $A$ berbanding tipe rumah $B$ berbanding tipe rumah $C$ dan berbanding tipe rumah $D$ adalah 1 berbanding 7 berbanding 1 berbanding 4 . Formulasi fungsi kendala alternatif pertama dengan batasan proporsi sesuai aspek pasar adalah :

- $\quad 7 x_{1} \leq x_{2} \rightarrow 7 x_{1}-x_{2} \leq 0$, diubah menjadi

$7 x_{1}-x_{2}+\quad+S_{4}=0$

- $\quad x_{2} \leq 7 x_{3} \rightarrow x_{2}-7 x_{3} \leq 0$, diubah menjadi

$$
x_{2}-7 x_{3}+\quad+S_{5}=0 \text {... }
$$

- $\quad 4 x_{3} \leq x_{4} \rightarrow 4 x_{3}-x_{4} \leq 0$, diubah menjadi

$$
4 x_{3}-x_{4}+\quad+S_{5}=0
$$

\section{e. Fungsi Tujuan}

Untuk menyusun fungsi tujuan yang dimaksimalkan adalah keuntungannya. Formulasi fungsi tujuan $(Z)$ dengan memaksimalkan keuntungan adalah :

$$
Z=80 x_{1}+62 x_{2}+48 x_{3}+38 x_{4}+0 S_{1}+0 S_{2}+0 S_{3}+0 S_{4}+0 S_{5}+0 S_{6}
$$

\subsection{Penyelesaian Model dengan Menggunakan Aplikasi QM for Windows}

QM for Windows merupakan aplikasi yang dirancang untuk melakukan perhitungan yang diperlukan pihak manajemen untuk mengambil keputusan baik bidang produksi maupun pemasaran. Software ini dirancang oleh Howard J. Weiss tahun 1996 untuk membantu penyusunan perkiraan anggaran untuk produksi bahan baku menjadi produk jadi atau setengah jadi pada produk pabrikasi. (Fauji, 2015).

QM for Windows merupakan perangkat lunak yang dikembangkan dan menyertai buku-buku teks seputar manajemen operasi yang diterbitkan oleh Prentice-Hall's. Terdapat tiga perangkat lunak sejenis yang mereka terbitkan yakni DS for Windows, POM for Windows 
dan QM for Windows. Perangkat-perangkat lunak ini user friendly dalam penggunaannya untuk membantu proses perhitungan secara teknis pengambilan keputusan secara kuantitatif. POM for Windows ialah paket yang diperuntukkan untuk manajemen operasi, QM for Windows ialah paket yang diperuntukkan untuk metode kuantitatif untuk bisnis dan DS for Windows berisi gabungan dari kedua paket sebelumnya. (Budi Harsanto, 2011).

Setelah nilai-nilai diinput, selanjutnya klik solve untuk mendapatkan hasil perhitungan seperti pada gambar dibawah ini.

Tabel 2 : Hasil perhitungan QM for Windows

\begin{tabular}{|c|c|c|c|c|c|c|c|}
\hline & X1 & X2 & X3 & X4 & & RHS & Dual \\
\hline Maximize & 80 & 62 & 48 & 38 & & & \\
\hline Constrain 1 & 320 & 248 & 192 & 152 & $<=$ & 10000 &, 25 \\
\hline Constrain 2 & 108 & 108 & 98 & 98 & $<=$ & 12500 & 0 \\
\hline Constrain 3 & 1 & 1 & 1 & 1 & $<=$ & 52 & 0 \\
\hline Constrain 4 & 7 & -1 & 0 & 0 & $<=$ & 0 & 0 \\
\hline Constrain 5 & 0 & 1 & -7 & 0 & $<=$ & 0 & 0 \\
\hline Constrain 6 & 0 & 0 & 4 & -1 & $<=$ & 0 & 0 \\
\hline Solution-> & 3,5014 & 24,5098 & 3,5014 & 14,0056 & Optimal Z-> & 2500 & \\
\hline
\end{tabular}

Hasil dari penyelesaian menggunakan aplikasi QM for Windows diperoleh nilai $X_{1}, X_{2}, X_{3}$ dan $X_{4}$ yaitu sebagai berikut :

$X_{1}=3,5 ; X_{2}=24,5 ; X_{3}=3,5 ; X_{4}=14$

Solusi ini menghasilkan nilai non-integer, sehingga digunakan metode integer untuk menghasilkan nilai integer optimal. Nilai integer tipe rumah $X_{1}, X_{2}, X_{3}$ dan $X_{4}$ adalah sebagai berikut :

$X_{1}=3$ dan $X_{1}=4 ; X_{2}=24$ dan $X_{2}=25 ; X_{3}=3$ dan $X_{3}=4 ; X_{4}=14$

Nilai integer yang diperoleh digunakan untuk menghitung jumlah tipe rumah yang memenuhi batasan-batasan yang ada dengan berbagai alternatif seperti berikut : 
Tabel 3

: Alternatif Pembulatan Jumlah Tipe Rumah dan Perolehan Keuntungan

\begin{tabular}{|c|c|c|c|c|c|c|c|c|c|c|c|c|c|c|c|c|c|c|c|}
\hline \multirow[b]{2}{*}{ Alternatif } & \multicolumn{4}{|c|}{ Jenis Rumah } & \multicolumn{4}{|c|}{ Batas lahan $\left(m^{2}\right)$} & \multicolumn{4}{|c|}{ Batas Biaya Produksi $(R p)$} & \multicolumn{4}{|c|}{ Laba $(R p)$} & \multirow{2}{*}{$\begin{array}{c}\text { Jumlah } \\
\text { Batas Lahan } \\
\left(\mathrm{m}^{2}\right)\end{array}$} & \multirow{2}{*}{$\begin{array}{l}\text { Jumlah batas } \\
\text { Biaya produksi }\end{array}$} & \multirow{2}{*}{$\begin{array}{l}\text { Total } \\
\text { laba } \\
(R p) \\
\end{array}$} \\
\hline & $X_{1}$ & $X_{2}$ & $X_{3}$ & $X_{4}$ & $X_{1}$ & $X_{2}$ & $X_{3}$ & $X_{4}$ & $X_{1}$ & $X_{2}$ & $X_{3}$ & $X_{4}$ & $X_{1}$ & $X_{2}$ & $X_{3}$ & $X_{4}$ & & & \\
\hline 1 & 3 & 24 & 3 & 14 & 108 & 108 & 98 & 98 & 320 & 248 & 192 & 152 & 80 & 62 & 48 & 38 & 4.582 & 9.616 & 2.404 \\
\hline 2 & 3 & 24 & 4 & 14 & 108 & 108 & 98 & 98 & 320 & 248 & 192 & 152 & 80 & 62 & 48 & 38 & 4.680 & 9.808 & 2.452 \\
\hline 3 & 3 & 25 & 3 & 14 & 108 & 108 & 98 & 98 & 320 & 248 & 192 & 152 & 80 & 62 & 48 & 38 & 4.690 & 9.864 & 2.466 \\
\hline 4 & 3 & 25 & 4 & 14 & 108 & 108 & 98 & 98 & 320 & 248 & 192 & 152 & 80 & 62 & 48 & 38 & 4.788 & 10.056 & 2.514 \\
\hline 5 & 4 & 24 & 3 & 14 & 108 & 108 & 98 & 98 & 320 & 248 & 192 & 152 & 80 & 62 & 48 & 38 & 4.690 & 9.936 & 2.484 \\
\hline 6 & 4 & 24 & 4 & 14 & 108 & 108 & 98 & 98 & 320 & 248 & 192 & 152 & 80 & 62 & 48 & 38 & 4.788 & 10.128 & 2.532 \\
\hline 7 & 4 & 25 & 3 & 14 & 108 & 108 & 98 & 98 & 320 & 248 & 192 & 152 & 80 & 62 & 48 & 38 & 4.798 & 10.184 & 2.546 \\
\hline 8 & 4 & 25 & 4 & 14 & 108 & 108 & 98 & 98 & 320 & 248 & 192 & 152 & 80 & 62 & 48 & 38 & 4.896 & 10.376 & 2.594 \\
\hline
\end{tabular}

Dari alternatif diatas yang memiliki keuntungan maksimal tanpa melebihi batasan-batasan yang telah ditetapkan adalah alternatif ke-5, jumlah tipe 80 sebanyak 4 unit, jumlah tipe 57 sebanyak 24 unit, jumlah tipe 50 sebanyak 3 unit dan jumlah tipe 42 sebanyak 14 unit dengan keuntungan sebesar Rp 2.484.000.000.-

Tabel $4 \quad$ : Perolehan keuntungan sebelumnya UD. Perumahan Griya Cempaka Alam

\begin{tabular}{|c|c|c|c|c|c|c|c|}
\hline \multirow{2}{*}{$\begin{array}{c}\text { Tipe } \\
\text { Rumah }\end{array}$} & \multirow{2}{*}{$\begin{array}{c}\text { Jumlah yang } \\
\text { Dibangun }\end{array}$} & $\begin{array}{c}\text { Harga } \\
\text { Produksi }\end{array}$ & Laba & Lahan & $\begin{array}{c}\text { Biaya } \\
\text { Produksi }\end{array}$ & Laba & Lahan \\
\cline { 2 - 8 } & 5 & 320 & 80 & 108 & 1600 & 400 & 540 \\
57 & 33 & 248 & 62 & 108 & 8184 & 2046 & 3564 \\
50 & 5 & 192 & 48 & 98 & 960 & 240 & 490 \\
42 & 21 & 152 & 38 & 98 & 3192 & 798 & 2058 \\
\hline \multicolumn{7}{|c|}{ Jumlah } \\
\hline
\end{tabular}




\subsection{Pembahasan}

Metode simpleks merupakan suatu algoritma, karena prosesnya dilakukan secara iteratif. Setiap prosedur iteratif merupakan suatu prosedur sistematis diulang-ulang (iterasi) sampai hasil yang dinginkan tercapai sehinggan penyelesaian pada iterasi tertentu adalah optimal.

Berdasarkan hasil penyelesaian dengan menggunakan metode simpleks diperoleh nilai $X_{1}=3,5, X_{2}=24,5, X_{3}=3,5$ dan $X_{4}=14$. Hasil tersebut berupa nilai pecahan desimal sehingga dilakukan pembulatan ke atas dan pembulatan kebawah, sehingga diperoleh $X_{1}=3$ atau $X_{1}=4$, $\mathrm{X}_{2}=24$ atau $\mathrm{X}_{2}=25, \mathrm{X}_{3}=3$ atau $\mathrm{X}_{3}=4$. Untuk nilai $\mathrm{X}_{4}$ tidak mengalami pembulatan dikarenakan hasil dari metode simpleks sudah merupakan bilangan bulat.

Berdasarkan nilai pembulatan diatas diperoleh delapan alternatif (Lihat tabel 4.2) yang menunjukkan bahwa alternatif ke-5 merupakan solusi optimal dengan keuntungan maksimal sebesar $\mathrm{Rp}$ 2.484.000.000.- dengan jumlah rumah yang diproduksi sebagai berikut jumlah rumah tipe 80 sebanyak 4 unit, jumlah rumah tipe 57 sebanyak 24 unit, jumlah rumah tipe 50 sebanyak 3 unit dan jumlah rumah tipe 42 sebanyak 14 unit.

Sebelum menggunakan metode simpleks Pada tabel 4.3 keuntungan yang diperoleh UD. Perumahan Griya Cempaka Alam sebesar Rp 3.484.000.000.-. Keuntungan yang diperoleh lebih besar dari keuntungan yang ada pada alternatif ke-5 tetapi biaya produksinya melebihi batasan 10 Milyar.

Hal ini menunjukkan bahwa hasil optimalisasi dengan menggunakan metode simpleks sangat membantu dalam perhitungan penentuan banyaknya jumlah masing-masing tipe rumah sehinggan perlu menjadi perhatian pengembang perumahan (developer) dalam melakukan perencanaan pembangunan perumahan berikutnya

\section{KESIMPULAN}

Berdasarkan hasil penelitian dengan menggunakan metode simpleks pada pembangunan perumahan UD. Perumahan Griya Cempaka Alam maka dapat disimpulkan bahwa :

1. Jumlah masing-masing tipe rumah yang akan dibangun yaitu rumah tipe 80 sebanyak 4 unit, rumah tipe 57 sebanyak 24 unit, rumah tipe 50 sebanyak 3 unit, dan rumah tipe 42 sebanyak 14 unit.

2. Keuntungan maksimal yang diperoleh UD. Perumahan Griya Cempaka Alam yaitu sebesar Rp 2.484.000.000.-. 


\section{DAFTAR PUSTAKA}

[1]. Budi Harsanto. 2011. Naskah Tutorial QM For Windows. Universitas Padjajaran. Bandung.

[2]. Fauji. 2015. Penerapan Metode Goal Programming untuk Mengoptimalkan Persediaan BBM di Kota Poso Berbasis Peningkatan Kendaraan (Studi Kasus: PT. Pertamina Upms VII Terminal BBM Poso Grup). Fakultas MIPA Universitas Tadulako. Palu.

[3]. Heinz F. 1999. Teori Perancangan Kota dan Penerapannya dalam Perancangan Kota Secara Terpadu. Yogyakarta.

[4]. Siringoringo. 2008. Metode Simpleks. http//learning.unram.ac.id/riset/pdf doc/modul/Dokumen/Simpleks.pdf, diakses 3 September 2014. 